Article History:

- $\quad$ Received 2018-03-22

- $\quad$ Revised 2018-03-27

- $\quad$ Accepted 2018-04-02
Media Publikasi Promosi Kesehatan Indonesia The Indonesian Journal of Health Promotion

\title{
ANALISIS PENYEBARAN PENYAKIT DEMAM BERDARAH DENGUE DI KOTA BANJARMASIN TAHUN 2012-2016
}

\author{
ANALYSIS OF DISEASES OF DENGUE HEALTHY FEVER DISEASES \\ IN THE BANJARMASIN CITY 2012-2016 \\ Kasman ${ }^{1}$, Nuning Irnawulan Ishak ${ }^{2}$ \\ ${ }^{1,2}$ Fakultas Kesehatan Masyarakat Universitas Islam Kalimantan MAB Banjarmasin \\ Email Korespondensi : kasman.ph@gmail.com
}

\begin{abstract}
Abstrak
Penyakit Demam Berdarah Dengue (DBD) telah menyebar luas ke seluruh wilayah di Provinsi Kalimantan Selatan dan terjadi di 13 (tiga belas) kota/kabupaten. Tujuan penelitian ini adalah untuk menganalisis sebaran kejadian penyakit Demam Berdarah Dengue (DBD) di Kota Banjarmasin tahun 2012-2016. Jenis penelitian yang digunakan dalam penelitian ini adalah penelitian studi deskriptif dengan unit pengamatan populasi melalui rancangan studi korelasi populasi dan rangkaian berkala atau time series. Penelitian ini akan dilaksanakan di Kota Banjarmasin yang dimulai pada bulan Agustus 2017 sampai bulan Desember 2017. Populasi dalam penelitian ini adalah seluruh data agregat penyakit DBD di Kota Banjarmasin selama tahun 2012-2016. Instrumen atau alat pengumpulan data dalam penelitian ini adalah menggunakan pedoman khusus berupa daftar check list untuk mengecek dan melengkapi kebutuhan data angka kejadian demam berdarah. Analisis data dilakukan secara univariat dan bivariat. Untuk melihat kekuatan hubungan antara variabel dependen dan variabel independen, maka dilakukan uji korelasi Pearson. Jika data tidak terdistribusi normal maka digunakan uji korelasi Spearman. Hasil penelitian ini menunjukkan bahwa kepadatan penduduk Kota Banjarmasin lebih banyak berpusat di Kecamatan Banjarmasin Barat dan Banjarmasin Tengah. Kejadian DBD terjadi secara fluktuatif dengan kejadian yang lebih banyak terjadi di Kecamatan Banjarmasin Timur. Secara umum tidak ada hubungan yang bermakna antara kepadatan penduduk di Kota Banjarmasin $(\mathrm{p}=0,726)$. Secara spesifik Kecamatan anjarmasin Utara memiliki korelasi kepadatan penduduk dengan kejadian DBD ( $p=0,042 ; r=0,892)$. Sementara 4 kecamatan lainnya tidak memiliki hubungan yang bermakna.
\end{abstract}

Kata Kunci : DBD, spasial, time series, kepadatan penduduk

\begin{abstract}
Dengue Hemorrhagic Fever (DHF) has spread to all areas in South Kalimantan Province and occurred in 13 (thirteen) cities / districts. The purpose of this research is to analyze the distribution of Dengue Hemorrhagic Fever (DBD) in Banjarmasin City in 2012-2016. The type of research used in this research is descriptive study with population observation unit through study of population correlation and period series. This research will be conducted in Banjarmasin city which started on August 2017 until December 2017. The population in this research is all aggregate data of dengue disease in Banjarmasin city during 20122016. Instrument or data collection tool in this research is using special guidance in the form of check list list to check and complete data requirement of dengue fever case. Data analysis was done univariat and bivariate. To see the strength of the relationship between the dependent variable and the independent variable, Pearson correlation test was performed. If the data is not normally distributed then Spearman correlation test is used. The results of this study indicate that the population density of Banjarmasin City is more centered in the District of West Banjarmasin and Banjarmasin Tengah. DHF incidence occurred in fluctuation with more incident happened in District Banjarmasin East. In general there is no significant relationship between population density in Banjarmasin City $(p=0,726)$. Specifically North Anjarmasin District has a population density correlation with $D B D$ incidence ( $p=0.042 ; r=0.892$ ). While 4 other sub-districts do not have a meaningful relationship.
\end{abstract}

Keywords: DHF, spatial, time series, population density 


\section{PENDAHULUAN}

Indonesia merupakan Negara hiperendemis Dengue dimana keempat serotipe virus Dengue sudah tersebar di 34 propinsi ${ }^{1}$. Sementara pada tahun 2014, sampai pertengahan bulan Desember tercatat penderita DBD di 34 provinsi sebanyak 71.668 orang dan 641 diantaranya meninggal dunia dengan CFR $0,9 \%$ (Kemenkes RI, 2015). Salah satu wilayah yang merupakan endemis DBD adalah Provinsi Kalimantan Selatan. Penyakit Demam Berdarah Dengue (DBD) telah menyebar luas ke seluruh wilayah di Provinsi Kalimantan Selatan dan terjadi di 13 (tiga belas) kota/kabupaten.

Menurut teori The Environment of Health yang dikemukakan oleh Hendrik L. Blum tahun 1974, konsep sehat dibagi menjadi 4 faktor yang berperan dalam status kesehatan. Empat faktor tersebut meliputi hereditas, gaya hidup, faktor pelayanan kesehatan dan lingkungan. Lingkungan sendiri adalah semua faktor luar yang berpengaruh pada suatu individu. Faktor lingkungan meliputi lingkungan fisik (rumah sehat), lingkungan biologi (angka bebas jentik $<95 \%$ ) dan lingkungan non fisik (kepadatan penduduk yang tinggi). Faktor lingkungan fisik dan biologi dapat mempengaruhi perkembangbiakan dan pertumbuhan vektor nyamuk Aedes aegypti, sedangkan faktor lingkungan non fisik dapat mempengaruhi persebarluasan penularan penyakit $\mathrm{DBD}^{2}$.

Data Dinas Kesehatan Kota Banjarmasin menunjukkan bahwa kejadian DBD selama empat tahun terakhir cenderung mengalami peningkatan. Tahun 2013 tercatat 33 kasus dan 1 kematian, tahun 2014 kemudian mengalami penurunan menjadi 11 kasus, tahun 2015 mengalami peningkatan lebih 6 kali lipat menjadi 75 kasus dengan 5 kematian, dan tahun 2016 terjadi 57 kasus dan 1 kematian ${ }^{3}$. Laporan BPS Provinsi Kalimantan Selatan tahun 2016, kepadatan penduduk tertinggi berada di kota Banjarmasin dengan jumlah kepadatan penduduk sebesar 9419,93 orang $/ \mathrm{km}^{2}{ }^{4}$. Kepadatan penduduk yang tinggi dapat meningkatkan penularan kasus DBD. Nyamuk memiliki kemampuan terbang hingga 100 meter, namun dengan penduduk yang padat, nyamuk tidak perlu terbang sejauh itu sehingga peluang besar untuk nyamuk Aedes aegypti menggigit pada banyak orang dapat memberikan dampak penyebaran kasus DBD dengan cepat ${ }^{5}$.

Adanya penyajian informasi dalam bentuk pemetaan penyebaran penyakit dapat membantu dalam mendapatkan data secara tepat dan akurat mengenai persebaran penyakit yang terdapat di suatu daerah ${ }^{2}$. Penyelesaian masalah DBD dapat dilakukan dengan teknik analisis manajemen penyakit berbasis wilayah dengan analisis spasial. Keberadaan suatu sistem informasi mengenai pemetaan penyebaran penyakit merupakan solusi yang tepat untuk membantu menanggulangi permasalahan tentang penyakit di suatu daerah. Peneliti dalam penelitian ini akan melakukan analisis spatial temporal (ruang dan waktu) untuk melihat sebaran kejadian DBD berdasarkan kepadatan penduduk yang berpengaruh terhadap kejadian DBD sehingga dapat membantu mengetahui daerah yang tergolong endemis DBD.

\section{METODE}

Desain penelitian yang digunakan dalam penelitian ini adalah Cross Sectional dengan unit pengamatan populasi melalui rancangan Ecologycal Study. Penelitian dilaksanakan pada tahun 2017 dengan menggunakan seluruh data agregat penyakit DBD dan data Geografi Kota Banjarmasin tahun 2012-2016. Pengolahan dan analisis data menggunakan program SPSS dan Archview.

\section{HASIL}

Tabel 1 (lampiran) menunjukkan kepadatan penduduk berdasarkan wilayah kecamatan di Kota Banjarmasin tahun 2012-2016. Data menunjukkan bahwa dalam rentang tahun 2012 sampai 2016, Kecamatan Banjarmasin Barat dan Banjarmasin Tengah memiliki kepadatan penduduk yang lebih besar dibandingkan kecamatan lainnya. Kecamatan Banjarmasin Tengah merupakan wilayah terpadat Kota Banjarmasin tahun 2012 dengan 13.898/Km2. Tahun 2013, Kecamatan Banjarmasin Barat paling padat dengan 11.031 jiwa/ 
Km2. Tahun 2014, Kecamatan Banjarmasin Tengah merupakan wilayah terpadat dengan 11.117 jiwa $/ \mathrm{Km} 2$. Tahun 2015, Kecamatan Banjarmasin Tengah masih merupakan wilayah terpadat dengan 14.227 jiwa / Km2 . Untuk tahun 2016, Banjarmasin Barat merupakan wilayah terpadat dengan $11.271 \mathrm{jiwa} / \mathrm{Km}^{2}$.

Data kejadian DBD Kota Banjarmasin tahun 2012 -2016 berdasarkan jenis kelamin dapat dilihat pada tabel 2 (lampiran) dimana kejadian DBD di Kota Banjarmasin lebih banyak terjadi pada laki-laki (147 orang) dibandingkan perempuan (98 orang). Sebaran kasus DBD Kota Banjarmasin berdasarkan wilayah kecamatan, dapat dilihat bahwa kejadian kasus DBD Kota Banjarmasin lebih banyak terjadi di Kecamatan Banjarmasin Timur (gambar 1-5). Kecamatan Banjarmasin Timur merupakan wilayah dengan kasus DBD terbesar yakni 20 kasus. Tahun 2013, Kecamatan Banjarmasin Timur paling banyak kasus DBD dengan 11 kasus. Tahun 2014, Kecamatan Banjarmasin Timur merupakan wilayah dengan kasus DBD terbanyak yakni 5 kasus. Tahun 2016, Kecamatan Banjarmasin Barat merupakan wilayah dengan kasus DBD terbanyak yakni 19 kasus. Untuk tahun 2016, Banjarmasin Timur merupakan wilayah dengan kasus DBD terbanyak yakni 18 kasus. Secara umum kejadian kasus DBD di Kota Banjarmasin tahun 2012-2014 terjadi trend penurunan kasus dari 67 kasus pada tahun 2012, kemudian menurun menjadi 33 kasus pada tahun 2013, dan menurun lagi menjadi 11 kasus tahun 2014. Tahun 2015 mengalami peningkatan yang sangat signifikan dengan 75 kasus, dan mengalami penurunan pada tahun 2016.

Korelasi kepadatan penduduk dengan kejadian DBD di Kota Banjarmasin tahun 2012-2106 dapat dilihat pada tabel 3 (lampiran) yang menunjukkan bahwa pengaruh kepadatan penduduk setiap wilayah kecamatan di Kota Banjarmasin tahun 2012-2016 mengalami perbedaan. Dari 5 kecamatan, hanya 1 kecamatan yakni Kecamatan Banjarmasin Utara yang memiliki korelasi kepadatan penduduk dengan kejadian DBD $(\mathrm{p}=0,042)$ dengan nilai korelasi 0,892 , artinya $89,2 \%$ kejadian DBD dipengaruhi oleh kepadatan penduduk. Sedangkan untuk wilayah Banjarmasin secara keseluruhan tidak menunjukkan adanya korelasi antara kepadatan penduduk dengan kejadian DBD $(\mathrm{p}=0,726)$.

\section{PEMBAHASAN}

Penyakit DBD merupakah penyakit endemis di Kota Banjarmasin dengan setiap tahunnya selalu terjadi kasus DBD, bahkan sering menimbulkan Kejadian Luar Biasa (KLB) dan mengakibatkan kematian pada masyarakat. Penyakit DBD termasuk penyakit infeksi yang disebabkan oleh virus dengue. Virus dengue mengakibatkan spectrum manifestasi klinis yang bervariasi mulai yang paling ringan, demam dengue (DD), DBD dan demam dengue yang disertai rejatan atau Dengue Shock Syndrom (DSS) ${ }^{2,6 .}$

Hasil penelitian ini menunjukkan bahwa kejadian kasus DBD di Kota Banjarmasin dalam rentang tahun 2012-2106 terjadi fluktuatif, dimana terjadi trend penurunan kasus dari tahun 2012 hingga 2014 beturutturut 67 kasus, 33 kasus, dan 11 kasus. Tetapi mengalami peningkatan 5 kali lipat lebih pada tahun 2015 dengan 75 kasus. Dan tahun 2016 mengalami penurunan menjadi 58 kasus.

Dalam epidemiologi Demam Berdarah, ada hubungan yang saling berkaitan antara host (manusia), agent (virus), dan environment (lingkungan fisik, kimiawi, biologik, sosial), lingkungan yang memberi kontribusi terhadap perkembangbiakan vektor (Aedes). Dengan demikian, ketiga faktor tersebut di atas mempengaruhi persebaran kasus DBD dalam suatu wilayah tertentu ${ }^{7}$.

Kondisi lingkungan di Kota Banjarmasin mendukung berkembangbiaknya virus DBD sehingga kejadian DBD selalu muncul setiap tahun. Banyaknya komplek perumahan penduduk yang biasanya memiliki tempat penampungan air serta pekarangan rumah dapat berisiko menjadi sumber penularan DBD. Hal ini dikarenakan banyaknya tempat yang mudah menjadi sarang nyamuk, seperti pekarangan rumah, tempat penampungan air, dan kaleng-kaleng kosong yang dibuang sembarangan. Bahkan keberadaan tanaman hias bisa menjadi faktor risiko munculnya kejadian DBD. Hasil 
penelitian yang dilakukan oleh Nova, dkk membuktikan bahwa nyamuk Aedes aegypti yang merupakan vektor penular DBD lebih banyak ditemukan di perkotaan pada areal permukiman dimana keberadaan tanaman hias lebih dominan ${ }^{8}$.

Penelitian ini juga menunjukkan bahwa kejadian DBD lebih banyak terjadi pada laki-laki (147 orang) dibandingkan dengan perempuan (98 orang). Hal ini dikarenakan faktor mobilitas yang berbeda antara lakilaki dan perempuan. Laki-laki pada dasarnya lebih banyak menghabisakan waktunya di luar rumah, sehingga risiko untuk tergigit nyamuk semakin besar. Penelitian Herlina Susmaneli juga menunjukkan bahwa kejadian DBD lebih banyak pada laki-laki $(53,7 \%)$ dibandingkan dengan perempuan ${ }^{9}$.

Kepadatan penduduk di suatu wilayah bisa berdampak pada penyebaran penyakit DBD ${ }^{7,10,11}$. Penyakit DBD ditularkan melalui vector nyamuk yang mempunyai kemampuan terbang sampai jarak 100 meter $^{7}$. Sehingga wilayah dengan kepadatan penduduk yang tinggi memiliki risiko penularan melalui nyamuk harus diwaspadai, karena kemampuan daya terbang nyamuk yang dekat.

Kepadatan penduduk adalah rata-rata jumlah penduduk pada luas wilayah $1 \mathrm{~km}$ persegi. Kepadatan penduduk di daerah yang dekat dengan pusat kota cenderung lebih tinggi, dibandingkan dengan kepadatan penduduk di daerah pinggiran kota 12. Kepadatan penduduk di Kota Banjarmasin termasuk kategori padat jika mengacu pada Badan Pusat Statistik. Kecamatan Banjarmasin Barat dan Banjarmasin Tengah merupakan daerah dengan kepadatan penduduk paling tinggi di Kota Banjarmasin. Hal ini dikarenakan Kecamatan Banjarmasin Tengah merupakan pusat Kota Banjarmasin. Ketersediaan fasilitas di pusat kota yang lebih maju dan lengkap tentunya menjadi daya tarik masyarakat untuk tinggal di pusat kota. Selain itu banyaknya pendatang yang menetap di pusat kota membuat semakin tingginya kepadatan penduduk. Pemukiman yang padat penduduk lebih rentan terjadi penularan DBD utamanya pada daerah perkotaan (urban) karena jarak terbang nyamuk Ae- des diperkirakan 50-100 meter. Pada daerah yang berpenduduk padat disertai distribusi nyamuk yang tinggi, potensi transmisi virus meningkat dan bertendensi ke arah terbentuknya suatu daerah endemis ${ }^{7}$.

Hasil penelitian ini menujukkan korelasi kepadatan penduduk terhadap kejadian DBD. Secara umum tidak terdapat korelasi antara kepadatan penduduk diseluruh wilayah kecamatan di Kota Banjarmasin $(p=0,726)$. Secara spesifik untuk setiap wilayah kecamatan, hanya Kecamatan Banjarmasin Utara yang memiliki korelasi kepadatan penduduk dengan kejadian DBD $(p=0,042)$. Ini menunjukkan kejadian DBD di Kecamatan Banjarmasin Utara mengikuti kepadatan penduduk. Semakin besar kepadatan penduduknya, maka semakin banyak pula kejadian DBD di kecamatan ini. Beberapa hasil penelitian menunjukkan kejadian DBD cenderung mengikuti kepadatan penduduk tinggi 13,14

Hal ini kemungkinan besar diperkuat dengan kondisi lingkungan yang ada di Kecamatan Banjarmasin Utara. Berdasarkan data dari BPS Kota Banjarmasin, Kecamatan Banjarmasin Utara terletak pada ketinggian 0,16 meter dibawah permukaan laut, dengan kondisi daerah berpaya - paya dan relative datar sehingga hampir seluruh wilayah digenangi air 4. Kondisi ini memungkinkan untuk terjadinya perindukan nyamuk karena terjadinya genangan air dimana-mana. Kondisi ini pada akhirnya akan mengakibatkan angka bebas jentik ( $\mathrm{ABJ}$ ) yang rendah. Rendahnya $\mathrm{ABJ}$ akan berakibat semakin tingginya kasus DBD ${ }^{15}$.

Faktor memang berpengaruh terhadap kepadatan populasi Aedes spp. Penelitian yang dilakukan di Kabupaten Karanganyar memperlihatkan bahwa kepadatan nyamuk dewasa pada dataran rendah ( $<500$ meter di atas permukaan laut) 4.5 kali lebih banyak dibandingkan pada dataran tinggi $(>500$ meter di atas permukaan laut). Selain itu usia nyamuk di dataran rendah lebih tua daripada temuan nyamuk di dataran tinggi. Larva Ae. aegypti yang ditemukan di dataran rendah 4 kali lebih banyak dibandingkan di dataran tinggi $^{16 .}$ 


\section{KESIMPULAN}

Penelitian ini menyimpulkan bahwa bahwa kejadian kasus DBD di Kota Banjarmasin dalam rentang tahun 2012-2106 terjadi fluktuatif, kejadian DBD lebih banyak terjadi pada laki-laki (147 orang) dibandingkan dengan perempuan (98 orang), serta korelasi kepadatan penduduk terhadap kejadian DBD. Secara umum tidak terdapat korelasi antara kepadatan penduduk diseluruh wilayah kecamatan di Kota Banjarmasin. Olehnya itu diharapkan perhatian penuh dari pemerintah tentang kejadian DBD.

\section{UCAPAN TERIMA KASIH}

Ucapan terima kasih disampaikan kepada

1. Ketua Yayasan Universitas Islam Kalimantan (UNISKA) Banjarmasin

2. Rektor Universitas Islam Kalimantan (UNISKA) Banjarmasin

3. Kepala Lembaga Pusat penelitian dan Pengabdian pada Masyarakat Universitas Islam Kalimantan (UNISKA) Banjarmasin

4. Kepala Pusat Penelitian Universitas Islam Kaliman$\tan$ (UNISKA) Banjarmasin

5. Dekan FKM Universitas Islam Kalimantan (UNISKA) Banjarmasin

6. Dinas Kesehatan Kota Banjarmasin

7. Badan Pusat Statistik Kota Banjarmasin

\section{DAFTAR PUSTAKA}

1. Fullerton LM, Dickin SK, Schuster-Wallace CJ. Mapping Global Vulnerability to Dengue Using the Water Associated Disease Index Mapping Global Vulnerability to Dengue Using the Water Associated Disease Index. CANADA: United Nations University; 2014. http://inweh.unu.edu.

2. Candra A. Demam Berdarah Dengue :

Epidemiologi, Patogenesis, dan Faktor Risiko Penularan. Aspirator. 2010;2(2):110-119. https:// media.neliti.com/media/publications/53636-IDdemam-berdarah-dengue-epidemiologipatog.pdf.
3. Dinas Kesehatan Kota Banjarmasin. Laporan Kasus DBD Di Kota Banjarmasin Tahun 20132016. Banjarmasin: Dinas Kesehatan Kota Banjarmasin Provinsi Kalimantan Selatan; 2016.

4. Statistik BP. Kota Banjarmasin Dalam Angka 2017. Banjarmasin: BPS Kota Banjarmasin; 2017.

5. Hairani L. Gambaran Epidemiologi Demam Berdarah Dengue (DBD) dan Faktor-Faktor yang Mempengaruhi Angka Insidennya di Wilayah Kecamatan Cimanggis, Kota Depok. Skripsi Fak Kesehat Masy UI. 2009. http://lib.ui.ac.id/file? file $=$ pdf/abstrak-124729.pdf.

6. Faiz N, Rahmawati R, Safitri D. ANALISIS SPASIAL PENYEBARAN PENYAKIT DEMAM BERDARAH DENGUE DENGAN INDEKS MORAN DAN GEARY'S C (STUDI KASUS DI KOTA SEMARANG TAHUN 2011). J GAUSSIAN. 2013;2(1):69-78.

7. A. Arsunan Arsin. EPIDEMIOLOGI DEMAM BERDARAH DENGUE ( DBD ) DI INDONESIA. 1st ed. (Sade A, ed.). Makassar: MASAGENA PRESS; 2013.

8. Pramestuti N, Djati AP. DISTRIBUSI VEKTOR DEMAM BERDARAH DENGUE (DBD) DAERAH PERKOTAAN DAN PERDESAAN DI KABUPATEN BANJARNEGARA. Bul Penelit Kesehat. 2013;41(3):163-170.

9. Susmaneli H. Faktor-Faktor yang Berhubungan dengan Kejadian DBD di RSUD Kabupaten Rokan Hulu. J Kesehat Komunitas. 2011;1 (3):149-154. http://jurnal.htp.ac.id/index.php/ keskom/article/download/19/15/.

10. Masrizal, Sari NP. Analisis Kasus DBD Berdasarkan Unsur Iklim dan Kepadatan Penduduk Melalui Pendekatan GIS di Tanah Datar. J Kesehat Masy Andalas. 2016;10(2):166171.

11. Suhermanto, Suparmi. Demam Berdarah Dengue Berdasarkan Kepadatan Penduduk dan Curah Hujan. J Bahana Kesehat Masy. 2017;1(1):75- 
86.

12. Handayani S, Fannya P, Shelvy Haria Roza IA. Analisis Spasial Temporal Hubungan Kepadatan Penduduk Dan Ketinggian Tempat Dengan Kejadian DBD Kota Padang Temporal. $J$ KesehatanMedika Saintika. 2010;8(1):25-34.

13. Ruliansyah A, Yuliasih Y, Ridwan W,

Kusnandar AJ. Analisis Spasial Sebaran Demam Berdarah Dengue di Kota Tasikmalaya Tahun 2011 - 2015. Aspirator. 2017;9(2):85-90.

14. Kurniawati R, Wati DM, Ariyanto Y. Analisis Spasial Sebaran Kasus Demam Berdarah Dengue ( DBD ) di Kabupaten Jember Tahun 2014 Spatial Analysis of Dengue Hemorrhagic Fever Distribution in Jember 2014. 2015:1-7.

15. Kusuma AP, Sukendra DM. ANALISIS SPASIAL KEJADIAN DEMAM BERDARAH DENGUE BERDASARKAN ANGKA BEBAS JENTIK. J Ilm Permas. 2017;7(2):66-73.

16. Fajriatin Wahyuningsih. Analisis Kejadian Demam BErdarah Dengue diwilayah Kerja Puskesmas Kota Bekasi Tahun 2011-2013. 2014. http:// repository.uinjkt.ac.id/dspace/ bitstream/123456789/25541/1/Fajriatin Wahyuningsih - fkik.pdf.

\section{LAMPIRAN}

Tabel 1.

Kepadatan Penduduk Kota Banjarmasin Tahun 2012-2016 berdasarkan Wilayah Kecamatan

\begin{tabular}{lrrrrr}
\hline Kecamatan & $\mathbf{2 0 1 2}$ & $\mathbf{2 0 1 3}$ & $\mathbf{2 0 1 4}$ & $\mathbf{2 0 1 5}$ & $\mathbf{2 0 1 6}$ \\
\hline Banjarmasin & 8.59 & 8.80 & 7.70 & 9.26 & 9.48 \\
Utara & 1 & 6 & 6 & 3 & 8 \\
Banjarmasin & 11.1 & 11.0 & 10.2 & 11.4 & 11.2 \\
Barat & 54 & 31 & 62 & 04 & 71 \\
Banjarmasin & 13.9 & 8.03 & 11.1 & 14.2 & 8.16 \\
Tengah & 89 & 3 & 17 & 27 & 5 \\
Banjarmasin & 4.82 & 4.89 & 4.96 & 5.03 & 5.09 \\
Timur & 6 & 2 & 3 & 2 & 7 \\
Banjarmasin & 3.95 & 4.00 & 4.06 & 4.12 & 4.17 \\
Selatan & 0 & 6 & 4 & 0 & 5 \\
\hline Sumbr : BPS Kan
\end{tabular}

Sumber : BPS Kota Banjarmasin
Tabel 2.

Kejadian Penyakit DBD Kota Banjarmasin Tahun 2012-2016 berdasarkan Wilayah Kecamatan

\begin{tabular}{|c|c|c|c|c|}
\hline Tahun & Kecamatan & Laki-laki & Perempuan & Jumlah \\
\hline \multirow{5}{*}{2012} & $\begin{array}{l}\text { Banjarmasin } \\
\text { Utara }\end{array}$ & 4 & 6 & 10 \\
\hline & $\begin{array}{l}\text { Banjarmasin } \\
\text { Barat }\end{array}$ & 9 & 5 & 14 \\
\hline & $\begin{array}{l}\text { Banjarmasin } \\
\text { Tengah }\end{array}$ & 7 & 6 & 13 \\
\hline & $\begin{array}{l}\text { Banjarmasin } \\
\text { Timur }\end{array}$ & 14 & 6 & 20 \\
\hline & $\begin{array}{l}\text { Banjarmasin } \\
\text { Selatan }\end{array}$ & 6 & 4 & 10 \\
\hline \multirow{5}{*}{2013} & $\begin{array}{l}\text { Banjarmasin } \\
\text { Utara }\end{array}$ & 3 & 2 & 5 \\
\hline & $\begin{array}{l}\text { Banjarmasin } \\
\text { Barat }\end{array}$ & 4 & 1 & 5 \\
\hline & $\begin{array}{l}\text { Banjarmasin } \\
\text { Tengah }\end{array}$ & 2 & 2 & 4 \\
\hline & $\begin{array}{l}\text { Banjarmasin } \\
\text { Timur }\end{array}$ & 6 & 5 & 11 \\
\hline & $\begin{array}{l}\text { Banjarmasin } \\
\text { Selatan }\end{array}$ & 5 & 3 & 8 \\
\hline \multirow{5}{*}{2014} & $\begin{array}{l}\text { Banjarmasin } \\
\text { Utara }\end{array}$ & 1 & 0 & 1 \\
\hline & $\begin{array}{l}\text { Banjarmasin } \\
\text { Barat }\end{array}$ & 2 & 0 & 2 \\
\hline & $\begin{array}{l}\text { Banjarmasin } \\
\text { Tengah }\end{array}$ & 2 & 0 & 2 \\
\hline & $\begin{array}{l}\text { Banjarmasin } \\
\text { Timur }\end{array}$ & 5 & 0 & 5 \\
\hline & $\begin{array}{l}\text { Banjarmasin } \\
\text { Selatan }\end{array}$ & 1 & 0 & 1 \\
\hline \multirow{5}{*}{2015} & $\begin{array}{l}\text { Banjarmasin } \\
\text { Utara }\end{array}$ & 10 & 5 & 15 \\
\hline & $\begin{array}{l}\text { Banjarmasin } \\
\text { Barat }\end{array}$ & 10 & 9 & 19 \\
\hline & $\begin{array}{l}\text { Banjarmasin } \\
\text { Tengah }\end{array}$ & 7 & 4 & 11 \\
\hline & $\begin{array}{l}\text { Banjarmasin } \\
\text { Timur }\end{array}$ & 11 & 7 & 18 \\
\hline & $\begin{array}{l}\text { Banjarmasin } \\
\text { Selatan }\end{array}$ & 8 & 5 & 13 \\
\hline \multirow{5}{*}{2016} & $\begin{array}{l}\text { Banjarmasin } \\
\text { Utara }\end{array}$ & 6 & 8 & 14 \\
\hline & $\begin{array}{l}\text { Banjarmasin } \\
\text { Barat }\end{array}$ & 4 & 5 & 9 \\
\hline & $\begin{array}{l}\text { Banjarmasin } \\
\text { Tengah }\end{array}$ & 2 & 1 & 3 \\
\hline & $\begin{array}{l}\text { Banjarmasin } \\
\text { Timur }\end{array}$ & 10 & 8 & 18 \\
\hline & $\begin{array}{l}\text { Banjarmasin } \\
\text { Selatan }\end{array}$ & 8 & 6 & 14 \\
\hline \multicolumn{2}{|l|}{ Jumlah } & 147 & 98 & 245 \\
\hline
\end{tabular}


Tabel 3.

Pengaruh Kepadatan Penduduk dengan Kejadian DBD di Kota Banjarmasin tahun 2012-2106

\begin{tabular}{|c|c|c|c|c|}
\hline \multicolumn{2}{|l|}{ Wilayah } & $n$ & $\mathbf{p}$ & $\mathbf{r}$ \\
\hline \multicolumn{2}{|c|}{ Kecamatan Banjarmasin Barat } & 5 & 0,107 & 0,796 \\
\hline Kecamatan & Banjarmasin & 5 & 0,076 & 0,828 \\
\hline $\begin{array}{l}\text { Tengah } \\
\text { Kecamatan }\end{array}$ & Banjarmasin & 5 & 0,904 & 0,076 \\
\hline $\begin{array}{l}\text { Timur } \\
\text { Kecamatan }\end{array}$ & Banjarmasin & 5 & 0,513 & 0,393 \\
\hline $\begin{array}{l}\text { Selatan } \\
\text { Kecamatan I } \\
\text { Kota Banjar }\end{array}$ & rmasin Utara & $\begin{array}{c}5 \\
25\end{array}$ & $\begin{array}{l}\mathbf{0 , 0 4 2} \\
0,726\end{array}$ & $\begin{array}{c}0,892 \\
-0,074\end{array}$ \\
\hline
\end{tabular}

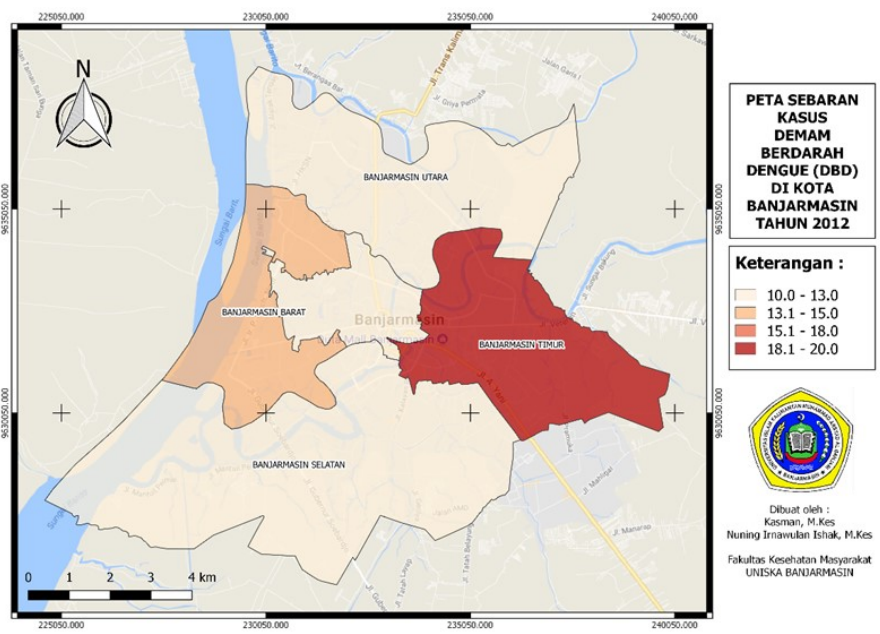

Gambar 1. Peta Sebaran Kasus Demam Berdarah Dengue (DBD) di Kota Banjarmasin tahun 2012

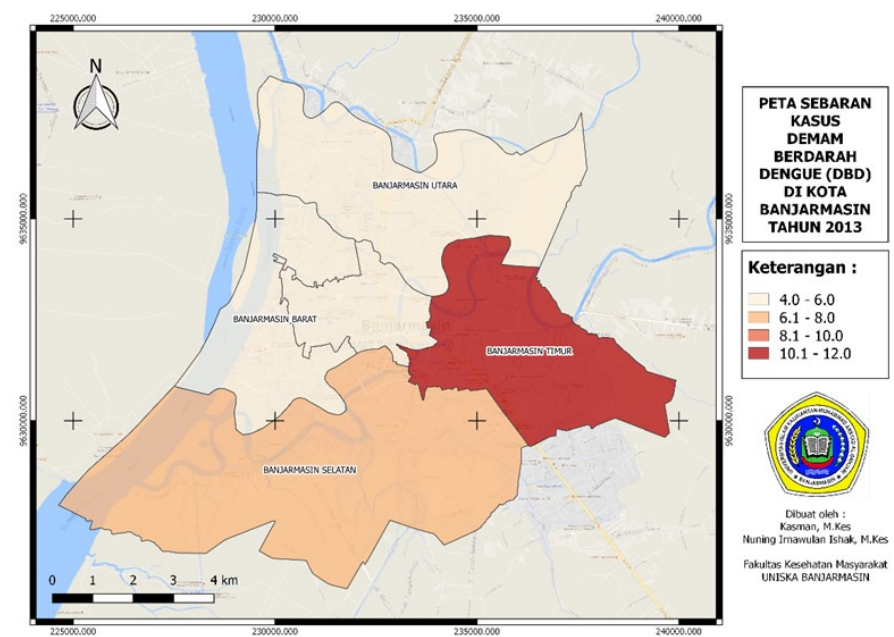

Gambar 2. Peta Sebaran Kasus Demam Berdarah Dengue (DBD) di Kota Banjarmasin tahun 2013

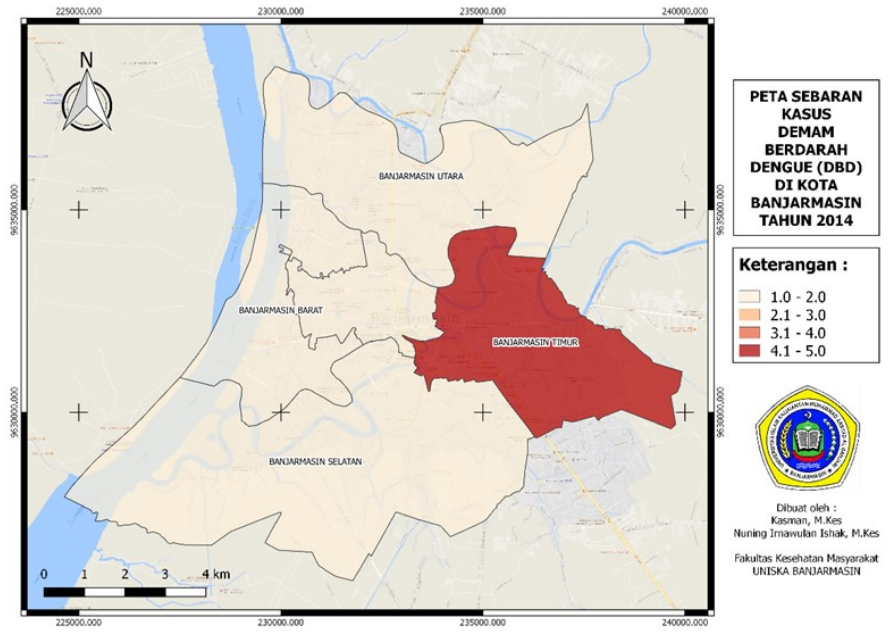

Gambar 3. Peta Sebaran Kasus Demam Berdarah Dengue (DBD) di Kota Banjarmasin tahun 2014

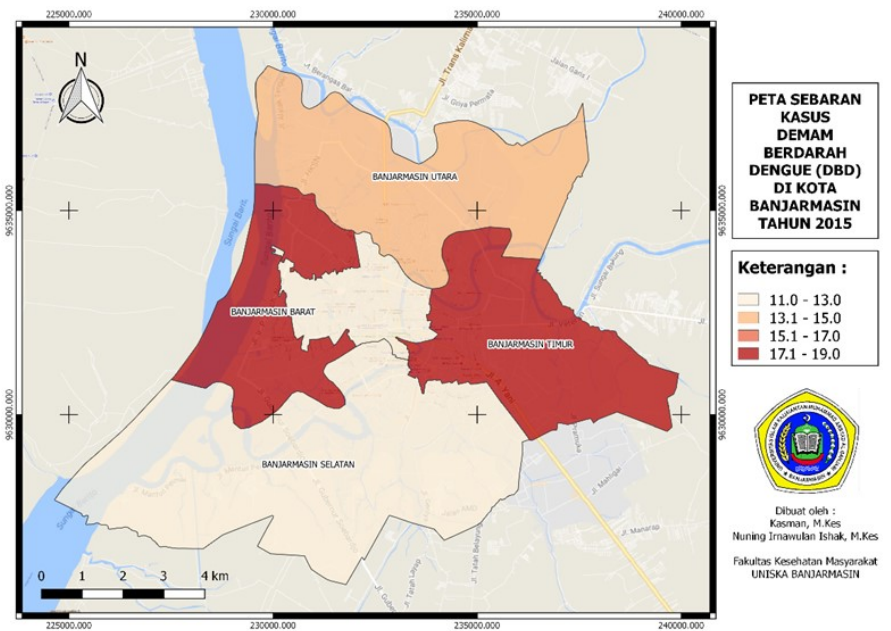

Gambar 4. Peta Sebaran Kasus Demam Berdarah Dengue (DBD) di Kota Banjarmasin tahun 2015

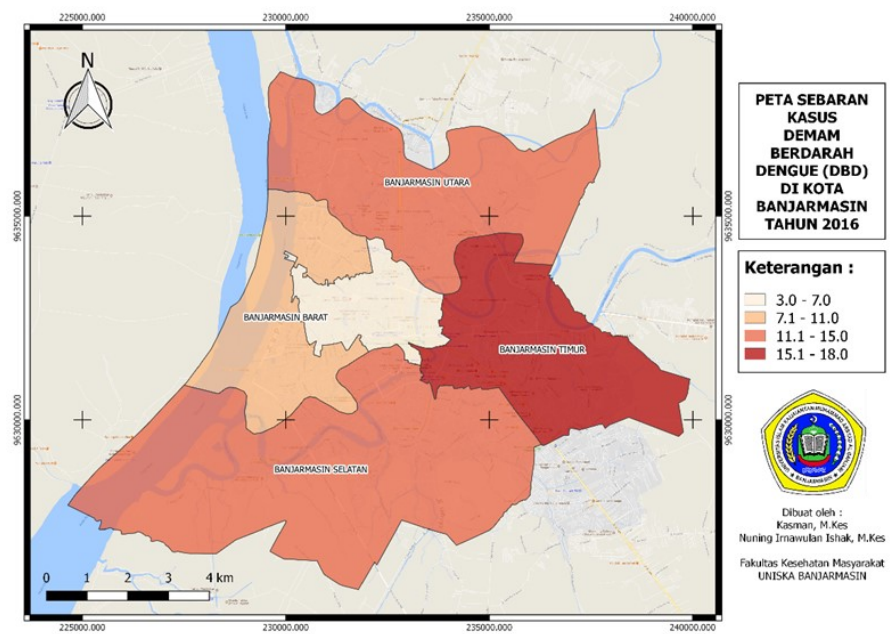

Gambar 5. Peta Sebaran Kasus Demam Berdarah Dengue (DBD) di Kota Banjarmasin tahun 2016 


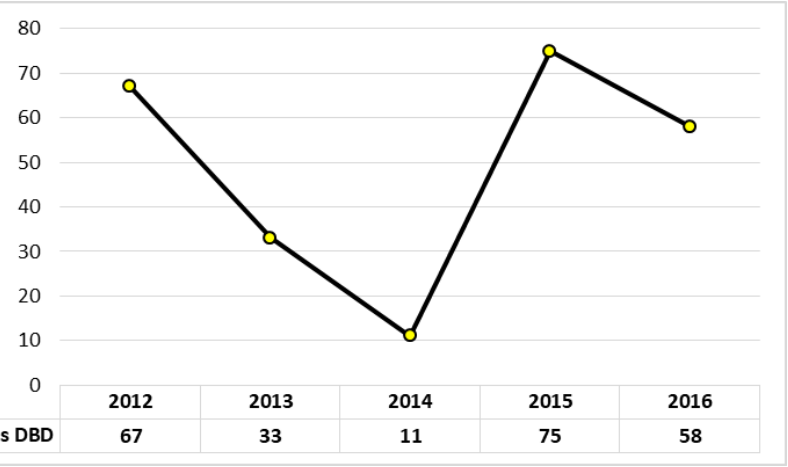

Gambar 6. Trend Kejadian DBD Kota Banjarmasin Tahun 2012-2016 